\title{
Humidifying system design of PEMFC test platform based on the mixture of dry and wet air
}

\author{
Ma Tiancai ${ }^{1}$, Xu Shi $^{1, a}$, Zhu Dong $^{1}$, Gu Rongxin ${ }^{1}$ \\ ${ }^{1}$ Clean Energy Automotive Engineering Center, Tongji University, Shanghai, China
}

\begin{abstract}
Based on the present humidifying system of PEMFC test platform, a novel design based on dry and wet air mixture is proposed. Key parameters are calculated, and test platform is built. Three experiments are implemented to test the performance of proposed design. Results show that the new design can meet the requirements, and realize the quick response and accurate control.
\end{abstract}

\section{Introduction}

Fuel cell test platform is an important tool to research the performance and durability of PEMFC (Proton exchange membrane fuel cell). The electrochemical reaction inside fuel cell stack is greatly influenced by air flowrate, temperature, humidity and pressure, consequently these air parameters need to be accurately controlled ${ }^{[1]}$. In regular humidifying systems, water is heated to humidify the air. Air is always humidified and heated at the same time, which leads to the coupling of air temperature and humidity control. Besides, due to the large inertia of water, the system response is slow. As a result, the regular humidifying system is difficult to achieve quick response and accurate control of air humidity. In this paper, a novel system design based on dry and wet mixture is proposed. By changing the proportion of dry and wet air flowrate, the humidity of mixed air is controlled. Furthermore, three experiments are conducted to test the control accuracy and the speed of response.

\section{Temperature and humidity range of test platform}

Air is supplied in fuel cell cathode. Air temperature influences reaction rate, catalyst activity, reactant transfer rate and etc. A higher air temperature is helpful for the reactant diffusion, and will enhance catalyst activity and improve the transfer of protons and water molecules. When the temperature is too high, however, it will cause membrane

dehydration and in contrary decrease fuel cell performances. Air humidity mainly effects protonic conductivity. Low hydration will also lead to membrane dehydration and decrease protonic conductivity. But when excessive water is present in the membrane resulting from overhydrating, water produced in cathode

\footnotetext{
${ }^{\mathrm{a}}$ Xu Shi: 15216758655@163.com
}

or electro osmatic drag effect, flooding will occur, block the reactant pathway and reduce the chemical reaction [2]. Present research shows that the optimal air temperature is between $60^{\circ} \mathrm{C}$ and $75^{\circ} \mathrm{C}^{[3][4]}$. And fuel cell stack shows the best performance when the air relative humidity is from $80 \%$ to $100 \%{ }^{[5-6]}$. The test platform should supply air whose parameters are up to $75^{\circ} \mathrm{C}$ and $\mathrm{RH} 100 \%$.

The humidity control should also meet the requirement of vehicle working conditions. Air supplied for cathode and stack output power of fuel cell used in vehicle vary quickly, which requires that the air supply system of test platform should achieve accurate control and quick response to simulate real conditions. As usual, the response of air flowrate and pressure control is fast, and the response time is millisecond. But for air temperature and humidity, the response time can be several minutes owing to large inertia [7]. Humidifying system in PEMFC test platform should meet requirements of high accuracy and quick response. The state 863 project (fuel cell engine dynamic performance test platform) requires that error of air dew temperature should be less than $5^{\circ} \mathrm{C}$ and response time less than 5 minutes.

\section{Humidifying system design}

Fig.1 shows humidifying methods commonly used in fuel cell stack include internal humidifying, external humidifying and self-humidifying.

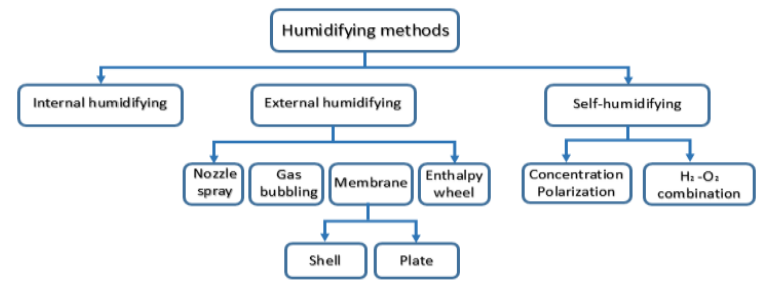

Figure 1 commonly used humidifying methods 
Test platform usually adopts external humidifier. Table 1 summaries the characteristics of currently used external

humidifiers [8] [9] [10].

Table 1 Contrast of external humidifiers

\begin{tabular}{|c|c|c|c|}
\hline Humidifier & Principle & Advantages & Disadvantages \\
\hline $\begin{array}{l}\text { Nozzle } \\
\text { Spray }\end{array}$ & $\begin{array}{c}\text { Atomizes water and sprays the } \\
\text { droplets uniformly on the reactant } \\
\text { gases }\end{array}$ & $\begin{array}{c}\text { Strong humidifying ability, control } \\
\text { humidity by changing water temperature } \\
\text { and spray quantity }\end{array}$ & $\begin{array}{l}\text { Droplets lead to stack flooding. Air humidity } \\
\text { is uniform. }\end{array}$ \\
\hline $\begin{array}{l}\text { Gas } \\
\text { Bubbling }\end{array}$ & $\begin{array}{l}\text { Reactant gases are humidified by } \\
\text { passing through bottles of heated } \\
\text { water }\end{array}$ & $\begin{array}{c}\text { Strong humidifying ability, control } \\
\text { humidity by changing water temperature } \\
\text { and gas flowrate }\end{array}$ & $\begin{array}{l}\text { Water supply system is complex. Humidity } \\
\text { is difficult to theoretically calculate. The } \\
\text { humidifying ability needs to be calibrated. }\end{array}$ \\
\hline membrane & $\begin{array}{l}\text { Membranes serve as separator. Gas } \\
\text { and water flow respectively on both } \\
\text { sides of membranes. Membranes } \\
\text { prevent gas and water mixing directly, } \\
\text { but allow the exchange of heat and } \\
\text { water molecules. }\end{array}$ & $\begin{array}{l}\text { System structure is compact. Lots of } \\
\text { researches have been done in this field. }\end{array}$ & $\begin{array}{l}\text { Membrane intensity is low. The pressure } \\
\text { difference on two sides of the membrane } \\
\text { needs to be accurately controlled. Humidity } \\
\text { system is complex. }\end{array}$ \\
\hline $\begin{array}{l}\text { Enthalpy } \\
\text { Wheel }\end{array}$ & $\begin{array}{l}\text { A rotating part driven by an electric } \\
\text { motor absorb water molecules and } \\
\text { heat from supplied water and transfer } \\
\text { them to gas used in fuel cell stack. }\end{array}$ & $\begin{array}{c}\text { Easy to control gas humidity by } \\
\text { changing rotation rate of enthalpy } \\
\text { wheel. }\end{array}$ & $\begin{array}{l}\text { System contains rotating parts, and the } \\
\text { rotation rate is high when high humidity is } \\
\text { required, which leads to vibration. }\end{array}$ \\
\hline
\end{tabular}

All of the humidifying methods mentioned below have conspicuous disadvantages if they are used in PEMFC test platform, and the low response speed problem still remains.

In this paper, a water heater is adopted to heat the water to boiling, and dry air is humidified by vapor. Fig. 2 shows the schematic diagram. Gas supply system is divided into two manifold branches in which dry and wet air is supplied respectively. By controlling the power of water heater, the gas in the wet manifold is fully humidified and the air temperature remains stable. Flowrate controller 1 and 2 control the flowrate proportion of the two manifolds, and the humidity of mixture air is accurately controlled. In addition, the enthalpy of mixture air equals the sum enthalpy of dry and wet air, as a result by controlling the power of air heater in dry air manifold, the mixture air temperature can be controlled.

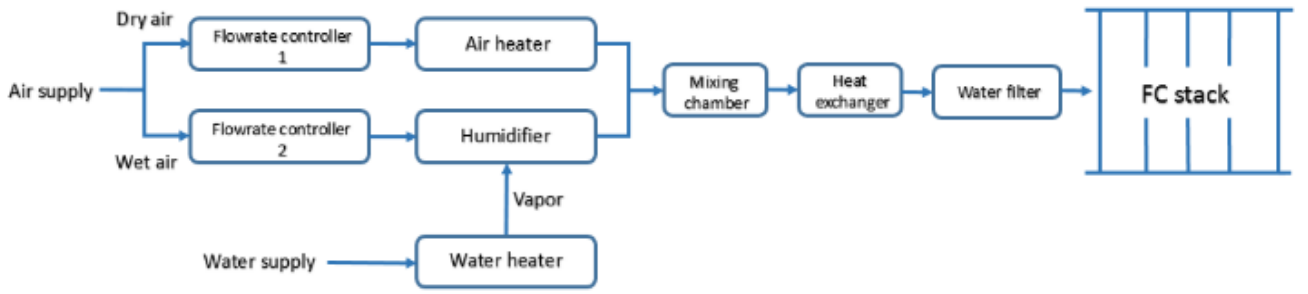

Figure 2 Schematic diagram of humidifying system

In this design, two actuators (air heater and flowrate controller) are used to achieve the decoupling control of air temperature and humidity. By changing the proportion of dry and wet air to control the humidity of mixture air, respond speed of the whole system is fast.

\section{Parameter design}

In this humidifying system design, water heater power, flowrate proportion of dry and wet air and air heater power are key parameters.

\subsection{Water heater power}

According to vapor quantity that required by wet air, power of water heater can be calculated. Based on Faraday equation [11], the air flowrate is:

$$
Q=\rho \cdot \dot{m}_{O_{2}}=\rho \cdot \dot{n}_{O_{2}} \cdot M_{O_{2}}=\frac{\rho \cdot P_{e} \cdot M_{O_{2}}}{4 F \cdot V_{C}}
$$

According to the unit moisture content $\mathrm{d}$, the required vapor can be calculated:

$$
\dot{m}_{\mathrm{H}_{2} \mathrm{O}}=d \cdot \dot{m}_{\text {air }}
$$

As a result, power of water heater is:

$$
P=\dot{m}_{\mathrm{H}_{2} \mathrm{O}} \cdot q+c_{p} \cdot \Delta T \cdot \dot{m}_{\text {air }}
$$

In the equation $\mathrm{C}_{\mathrm{p}}$ is specific heat at constant pressure and $\mathrm{q}$ is latent heat of vaporization.

\subsection{Estimate proportion of dry and wet air}

According to the design principle, the wet air parameters remain unchanged by controlling the water heater power. However the definite parameters need to be measured, consequently at first the parameters are estimated and then experiments are conducted to correct them. Assume the temperature of wet air is $75^{\circ} \mathrm{C}$, and $\mathrm{RH}$ is $100 \%$; $\mathrm{RH}$ of dry is $0 \%$. When the set dew temperature of mixture air is $T_{d p}$, the required unit moisture content $d_{d p}$ is [12]:

$$
\left\{\begin{array}{l}
\ln \left(P_{V-\text { sat }} \times 10^{-6}\right)=9.3876-\frac{3826.36}{T_{d p}+273.14-45.47} \\
d_{D P}=0.622 \times \frac{P_{V-\text { sat }}}{P-P_{V-\text { sat }}}
\end{array}\right.
$$

$\mathrm{P}$ is air pressure.

When the air dew temperature is $75{ }^{\circ} \mathrm{C}$, the unit moisture content is $0.3905 \mathrm{~g} / \mathrm{g}$. Flowrates of dry and wet air are calculated by the following equation: 


$$
\left\{\begin{array}{l}
Q_{w e t}=Q \times \frac{d_{D P}}{0.3905} \\
Q_{d r y}=Q-Q \times \frac{d_{D P}}{0.3905}=Q \times \frac{0.3905-d_{D P}}{0.3905}
\end{array}\right.
$$

$\mathrm{Q}$ is gross air flowrate which is gained by equation 1 .

\subsection{Power of air heater}

Equation can be established by air enthalpy. The enthalpy of mixture air equals the sum enthalpy of dry and wet air. Total enthalpy of air is calculated by the following formula [13]:

$$
H=m_{\text {air }} \times 1.005 \cdot t+m_{\mathrm{H}_{2} \mathrm{O}} \times(2501+1.86 \cdot t)
$$

$\mathrm{t}$ is air temperature.

If the required temperature of mixture air $\mathrm{T}$ is set, and wet air flowrate $\mathrm{Q}_{\text {wet }}$ and dry air flowrate $\mathrm{Q}_{\mathrm{dry}}=\mathrm{Q}-\mathrm{Q}_{\text {wet }}$ are calculated, the air enthalpy before and after mixture is:

Before mixture:

$$
\begin{aligned}
H_{1}= & H_{d r y}+H_{w e t} \\
H_{d r y}= & Q_{d r y} \times \rho_{\text {air }} \times 1.005 \times t_{d r y} \\
H_{\text {wet }}= & Q_{\text {wet }} \times \rho_{\text {air }} \times 1.005 \times D P_{\text {out }} \\
& +Q_{\text {wet }} \times \rho_{\text {air }} \times d_{D P_{\text {out }}} \times\left(2501+1.86 \times D P_{\text {out }}\right)
\end{aligned}
$$

After mixture:

$$
\begin{aligned}
H_{2}= & Q \times \rho_{\text {air }} \times 1.005 \times T \\
& +Q \times \rho_{\text {air }} \times d_{D P} \times(2501+1.86 \times T)
\end{aligned}
$$

$\mathrm{DP}_{\text {out }}$ is the ${ }_{\text {dew }}$ temperature of wet air at manifold outlet.

Due to $\mathrm{H}_{1}=\mathrm{H}_{2}$, the required dry air temperature $\mathrm{t}_{\mathrm{dry}}$ can be gained. As a result the power of air heater is:

$$
\begin{aligned}
P & =\frac{c_{a i r} \cdot Q_{d r y} \cdot \rho_{a i r} \cdot\left(t_{d r y}-t_{\text {initial }}\right)}{60} \\
& =\frac{4.2 \times Q_{d r y} \times 1.29 \times\left(t_{d r y}-t_{\text {initial }}\right)}{60} \\
& =0.09 \times Q_{d r y} \times \Delta t(\mathrm{~W})
\end{aligned}
$$

In this equation, $\mathrm{c}_{\text {air }}=4.2 \mathrm{~J} / \mathrm{g}, \rho_{\text {air }}=1.29 \mathrm{~g} / \mathrm{L}$.

According to equation from equation 1 to 9 , as long as the required mixture air temperature and dew temperature are set, key parameters in this design can be theoretically calculated, and the control of temperature and humidity are decoupling.

Even though the key parameters can be theoretically calculated, they are in fact influenced by pipe structure, vapor condensation and many other factors. The actual performances need to be tested.

\section{Experiments and results}

\subsection{The actual power of water heater}

Experiment 1 is to test whether the vapor is enough when water is heated by the theoretical power of water heater. Fig.3 shows the relationship between water heater power and wet air flowrate when the dew temperature of wet air at manifold outlet is $75 \pm 1{ }^{\circ} \mathrm{C}$.

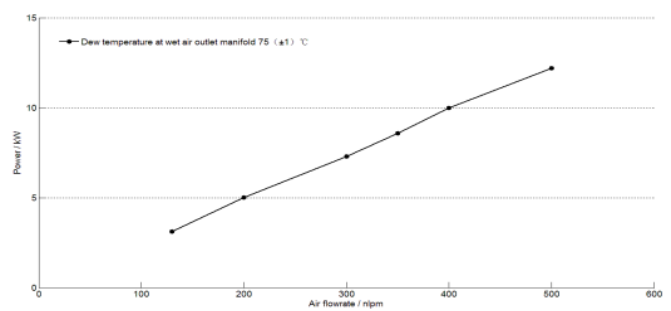

Figure 3 Wet air flowrate and water heater power

Fig.4 shows the difference of actual fitting curve and theoretical curve. Compared with the theoretical curve, actual water heater power is higher due to heat conduction by pipe, and the efficiency is $85.4 \%$.

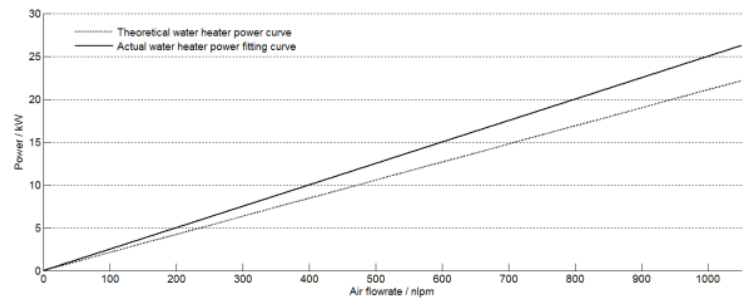

Figure 4 Actual water heater power fitting curve

The test results also show that at outlet of wet air manifold, the air dew temperature can reach $75^{\circ} \mathrm{C}$, but the air temperature is only $80^{\circ} \mathrm{C}$, which means the relative humidity is only $81.47 \%$.

The estimate flowrate proportion of dry and wet air is with hypothesis that wet air RH is $100 \%$, however the actual RH is only 81.47 , so the proportion needs to be corrected to achieve accurate humidity control of mixture air.

When the actual wet air temperature at outlet is $\mathrm{T}_{\text {out }}$, and actual dew temperature is $\mathrm{T}_{\text {dp-out, }}$ which are tested by dew temperature sensor, the actual $\mathrm{RH}$ is:

$$
R H_{\text {out }}=\frac{e^{\frac{9.3876-3826.36}{T_{\text {dpout }}+273.15-45.47}}}{e^{\frac{9.3876-3826.36}{T_{\text {out }}+273.15-45.47}}}=e^{\frac{-3816.9724\left(T_{\text {out }}-T_{\text {dopout }}\right)}{\left(T_{\text {dpout }}+227.68\right)\left(T_{\text {out }}+227.68\right)}} \times 100 \%
$$

The actual unit moisture content is:

$$
\left\{\begin{array}{l}
\ln \left(P_{V \text {-sat }} \times 10^{-6}\right)=9.3876-\frac{3826.36}{T_{\text {out }}+273.14-45.47} \\
d_{D P_{\text {out }}}=0.622 \times \frac{R H_{\text {out }} \times P_{V-\text { sat }}}{P-R H_{\text {out }} \times P_{V-\text { sat }}}
\end{array}\right.
$$

As a result, the actual flowrate proportion can be calculated by the following equation:

$$
\left\{\begin{array}{l}
Q_{\text {wet-actual }}=Q \times \frac{d_{D P}}{d_{D P_{o u t}}} \\
Q_{d r y \text {-actual }}=Q-Q \times \frac{d_{D P}}{d_{D P_{\text {out }}}}=Q \times \frac{d_{D P_{o u t}}-d_{D P}}{d_{D P_{\text {out }}}}
\end{array}\right.
$$

\subsection{The actual mix results of dry and wet air}

According to experiment 1 , the actual water heat power and flowrate proportion are gained. Experiment 2 is to 
test that whether the dry and wet air mix in a proper way. Table 2 shows the experiments condition and mix results.

Table 2 Actual mix results of wet and dry air

\begin{tabular}{|c|c|c|c|c|c|c|}
\hline $\begin{array}{l}\mathrm{N} \\
\text { o. }\end{array}$ & $\begin{array}{l}\text { Dry air } \\
\text { flowrate } \\
\text { (nlpm) }\end{array}$ & $\begin{array}{c}\text { Wet air } \\
\text { flowrat } \\
\text { e(nlpm } \\
\text { ) }\end{array}$ & $\begin{array}{c}\text { Outlet } \\
\text { temper } \\
\text { ature } \\
\left({ }^{\circ} \mathrm{C}\right)\end{array}$ & $\begin{array}{l}\text { Outlet } \\
\text { dew } \\
\text { temper } \\
\text { ature } \\
\left({ }^{\circ} \mathrm{C}\right)\end{array}$ & $\begin{array}{l}\text { RH } \\
(\%)\end{array}$ & $\begin{array}{c}\text { Unit } \\
\text { moisture } \\
\text { content } \\
(\mathrm{g} / \mathrm{g})\end{array}$ \\
\hline \multirow{3}{*}{1} & 100 & 0 & 25.0 & 23.0 & 88.6 & 0.018 \\
\hline & 0 & 100 & 92.0 & 87.9 & 85.6 & 1.013 \\
\hline & 100 & 100 & 86.7 & 84.2 & 90.6 & 0.770 \\
\hline \multirow{3}{*}{2} & 150 & 0 & 25.0 & 23.0 & 88.6 & 0.018 \\
\hline & 0 & 150 & 89.2 & 85.9 & 88.2 & 0.904 \\
\hline & 150 & 150 & 82.3 & 80.9 & 94.8 & 0.587 \\
\hline \multirow{3}{*}{3} & 200 & 0 & 25.0 & 23.0 & 88.6 & 0.018 \\
\hline & 0 & 200 & 86.6 & 84.5 & 92.3 & 0.795 \\
\hline & 200 & 200 & $\begin{array}{l}78.8 \\
\end{array}$ & 77.9 & $\begin{array}{l}96.4 \\
\end{array}$ & 0.469 \\
\hline \multirow{3}{*}{4} & 250 & 0 & 25.0 & 23.0 & 88.6 & 0.018 \\
\hline & 0 & 250 & 84.9 & 81.1 & 85.9 & 0.596 \\
\hline & 250 & 250 & 76.5 & 75.1 & 94.4 & 0.384 \\
\hline
\end{tabular}

Table 3 shows the contrast of theoretical mix results and actual mix results.

Table 3 Contrast of theoretical and actual mix results

\begin{tabular}{|c|c|c|c|c|c|}
\hline No. & $\begin{array}{c}\text { Air } \\
\text { flowrate(dry } \\
\text { air + wet air } \\
\text { nlpm) }\end{array}$ & $\begin{array}{c}\text { Actual } \\
\text { moisture } \\
\text { content } \\
(\mathrm{g} / \mathrm{g})\end{array}$ & $\begin{array}{c}\text { Theoretical } \\
\text { moisture } \\
\text { content } \\
(\mathrm{g} / \mathrm{g})\end{array}$ & $\begin{array}{c}\text { Actual } \\
\text { dew } \\
\text { temper } \\
\text { ature } \\
\left({ }^{\circ} \mathrm{C}\right)\end{array}$ & $\begin{array}{c}\text { Theoreti } \\
\text { cal dew } \\
\text { temperat } \\
\text { ure } \\
\left({ }^{\circ} \mathrm{C}\right)\end{array}$ \\
\hline 1 & $100+100$ & 0.770 & 0.561 & 90.6 & 80.3 \\
\hline 2 & $150+150$ & 0.587 & 0.461 & 94.8 & 77.7 \\
\hline 3 & $200+200$ & 0.496 & 0.407 & 96.4 & 75.9 \\
\hline 4 & $250+250$ & 0.384 & 0.307 & 94.4 & 71.6 \\
\hline
\end{tabular}

The test result shows that the actual dew temperature is higher than theoretical dew temperature, which means the mixture air contains more vapor than expected. Analyze this phenomenon and the reason is: there is excessive vapor flow with wet air and mix with the original dry air, which leads to a higher dew temperature of mixture air. Hence to achieve an accurate humidity control, a steam filter is required before mixture of dry and wet air to remove redundant vapor.

\subsection{Test the accuracy and response time}

Experiment 3 is to test the accuracy and response time of the platform. 9 experiments are conducted, and the test conditions are $200(\mathrm{nlpm})$ wet air mix respectively with 100, 150, 200, 250(nlpm) dry air, and 100(nlpm) wet air mix respectively with $100,150,200,250,300(\mathrm{nlpm})$ dry air. Fig. 5 shows the results.

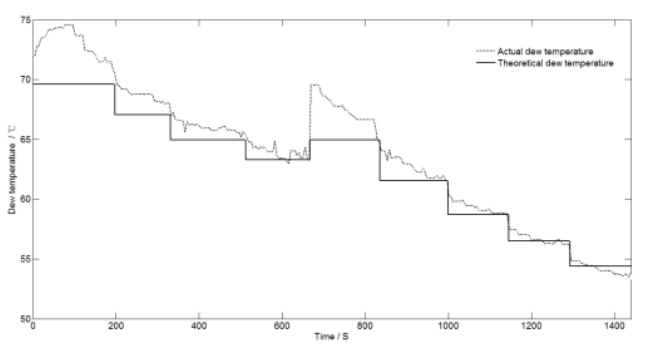

Figure 5 Contrast of theoretical and actual wet air dew temperature

This figure shows the actual response time and the error between actual dew temperature and theoretical dew temperature in different test conditions. At first, the actual dew temperature is still high due to the excessive vapor. When the test condition changes, the actual dew temperature responds quickly. it also shows that when the dew temperature error limit is set to be $2{ }^{\circ} \mathrm{C}$, the response time is 2 mins. The accuracy and response time can meet the requirements of vehicle dynamic working conditions.

\section{Conclusions}

As an important tool to research fuel cell system, PEMFC test platform needs to meet the requirements of vehicle dynamic working conditions, and achieve accurate control and quick response. Due to the large inertia and coupling of air temperature and humidity control, regular humidifying system is different to achieve the requirements mentioned above.

In this paper, a novel air humidifying system based on the mixture of dry and wet air is proposed. By controlling the flowrate proportion of dry and wet air, the humidity of mixture air is controlled, and by controlling the power of air heater, the temperature of mixture air is controlled. These two control lead to the decoupling of air temperature and humidity. Furthermore, key parameters are calculated and three experiments are implemented to test the performance of the test platform. The results show that the error of air dew temperature is less than $5^{\circ} \mathrm{C}$, and when the error limit is set to be $2^{\circ} \mathrm{C}$, the system response time is 2 mins. The humidifying system can achieve accurate control and quick response, and totally meet the requirements of vehicle working conditions.

\section{Acknowledgment}

This work was supported by state 863 project: Fuel cell engine dynamic performance test platform.

\section{References}

1. Ryan O'Hayre, Suk-Won Cha, Whitney Colella, Fritz B. Prinz, et al. Fuel Cell Fundamentals (second edition) [M]. Wiley, 2009.

2. Klaus Kreuer, Robert Meyers, Rita Colwell et al. Fuel Cells [M].Stuttgart in Germany.2012. 
3. Gui Wengang. The design and simulation of $25 \mathrm{~kW}$ FCPS's temperature management system [D]. Hubei: Wuhan University of Technology, 2009.

4. Sun Jia, Guo Hua, Chen Shizhong and Wu Yuhou. Experimental analysis of operating performance of PEM fuel cell-Effect of temperature on performance of PEM fuel cell. Journal of Shenyang Jianzhu University (Natural Science) [J], 2006, 22(06):10341037.

5. Zhang Lianhong, Jie Weiping, Xie Chungang, Xu Jiafu and Song Haimi. Effects of temperature, pressure and humidity on electric efficiency of PEMFC stack. Journal of Tianjin University [J]. 2007, 40(05):594-597.

6. Xie Jin and Huang Yunqian. Effects of temperature and humidity on the performance of proton exchange membrane fuel cells. Journal of shanghai maritime university [J]. 2005, 26(03):60-63.

7. Wei Aiguo. Study on model and control strategy in air supply system of PEMFC in vehicles [D].Hubei: Wuhan University of Technology, 2010.

8. Sang-Kyun Park, Song-Yul Choe and Seo-ho Choi. Dynamic modeling and analysis of a shell-and-tube type gas-to-gas membrane humidifier for PEM fuel cell applications. International Journal of Hydrogen Energy [J]. 33 (2008) 2273-2282.

9. Sangyu Kang, Kyoungkoug Min and Sangseok Yu. Two dimensional dynamic modeling of a shell-andtube water-to-gas membrane humidifier for proton exchange membrane fuel cell. International Journal of Hydrogen Energy [J]. 35 (2010) 1727-1741.
10. Beom Jun Kim and Min Soo Kim. Studies on the cathode humidification by exhaust gas recirculation for PEM fuel cell. International Journal of Hydrogen Energy [J]. 37 (2012) 4290-4299.

11. Yin Baolian. Fuel cell principle, technology and application [M]. Chemical Industry Press. 2003

12. Liu Hui, Zhang Hongtao and Xiao Hong. Contrast of Antoine equation parameters of saturated vapor pressure. Inner Mongolia petrochemical industry [J]. 2009(13):32-34.

13. Zhu Mingshan, Liu Ying and Lin Zhaozhuang. Engineering Thermodynamics (second edition) [M]. Press of Tsinghua University. 2011 